\title{
Cohort structures of high mountain forests in northeast Turkey: Case study of Kavron Valley
}

\author{
Zafer YÜCESAN*, Ali Ömer ÜÇLER, Ercan OKTAN \\ Karadeniz Technical University, Faculty of Forestry, 61080, Trabzon, TURKEY \\ *Corresponding author: yucesan@,ktu.edu.tr
}

Received Date: 25.01.2017

Accepted Date: 22.01 .2018

\section{Abstract}

Aim of the study: In this study, cohort structures of the high mountain forests in northeast Turkey were investigated.

Material and Methods: Eighteen plots were selected in six sampling units. Treeline, timberline and sub-timberline stands were sampled in each unit.

Main results: Structures varied from single-cohort to multi-cohort stands in the research area. The incidence of multiple cohort structures increased towards the timberline and treeline from the subtimberline. Tree ages ranged from 10 to 150 years in the treeline, 15 to 270 years in the timberline and 13 to 105 years in the sub-timberline. 8 sampled stands were pure and 10 stands were mixed stands. Mixed stands were composed by Sorbus aucuparia, Populus tremula, Fagus orientalis, Picea orientalis and Abies nordmanniana in the treeline. Picea orientalis, Fagus orientalis and Abies nordmanniana were tree species in mixed stands in the timberline and sub-timberline. However, Picea orientalis was dominant in all zones. Numbers of trees in the tree collectives ranged from 2 to 17 in the treeline, 3 to 9 in the timberline and 2 to 3 in the sub-timberline stands. Mean areas per tree in the collectives were $1.77 \mathrm{~m}^{2}$ in the treeline, $2.56 \mathrm{~m}^{2}$ in the timberline and $2.51 \mathrm{~m}^{2}$ in the sub-timberline. Numbers of tree collectives ranged from 6 to 7 in the treeline, 2 to 5 in the timberline and 2 to 3 in the sub-timberline stands.

Research highlights: Multi-cohort structures and tree collectives are key factors in silvicultural applications in high mountain forests. Silvicultural treatment such as single-tree selection method, patch and group selection method can be provided because of being suitable for multi-cohort structure.

Keywords: High mountain forest, Cohort structures, Treeline, Timberline, Sub-timberline

\section{Türkiye’nin kuzeydoğusundaki yüksek dağ ormanlarında meşcere}

\section{kurulușları: Kavron Vadisi örneği}

\section{Özet}

Çalışmanın amacı: Bu çalışmada, Türkiye'nin kuzeydoğusunda yer alan yüksek dağ ormanlarının meşcere yapıları araştırılmıştır.

Materyal ve Yöntem: 6 örnekleme ünitesinden toplam 18 örnek alanda çalışma gerçekleştirilmiştir. Her örnekleme ünitesinde ağaç sınırı, orman sınırı ve orman sınırı altından örnek alanlar alınmıştır.

Sonuçlar: Çalışma alanında meşcere yapılarının eşit yaşlı ve değişik yaşlı meşcere kuruluşları gösterecek şeklide değişkenliğe sahip olduğu belirlenmiştir. Ağaç sınırında ağaçların yaşları 10-150 arasında, orman sınırında 15-270 arasında ve orman sınırı altında 13-105 arasında değişmektedir. Örneklenen meşcerelerinin 8'I saf, 10'u ise karışık meşceredir. Karışık meşcerelerde karışım ağaç türlerini ağaç sınırında Sorbus aucuparia, Populus tremula, Fagus orientalis, Picea orientalis ve Abies nordmanniana oluşturmaktadır. Orman sınırında ve orman sınırı altında ise karışım ağaç türleri Picea orientalis, Fagus orientalis ve Abies nordmanniana'dır. Ancak, Picea orientalis bütün zonlarda baskın ağaç türü olarak görülmektedir. Ağaç topluluklarındaki birey sayıları ağaç sınırında 2-17, orman sınırında 3-9 ve orman sınırı altında 2-3 arasında değişmektedir. Ağaç topluluklarında ağaç başına düşen alan miktarı ağaç sınırında $1.77 \mathrm{~m}^{2}$, orman sınırında $2.56 \mathrm{~m}^{2}$ ve orman sınırı altında $2.51 \mathrm{~m}^{2}$ dir. Ağaç sınırında ağaç topluluğu sayısı 6-7, orman sınırında 2-5 ve orman sınırı altında 2-3 arasında değişmektedir.

Araştırma vurguları: Değişik yaşlılık ve ağaç topluluğu oluşumları yüksek dağ ormanlarındaki silvikültürel uygulamalar için anahtar faktörlerdir. Tek ağaç seçme işletmeciliği, grup veya büyük grup seçme işletmeciliği gibi silvikültürel uygulamalar, değişik yaşlı meşcere kuruluşu için uygun olmalarından dolayı tercih edilebilir.

Anahtar Kelimeler: Yüksek dağ ormanı, Meşcere kuruluşları, Ağaç sınırı, Orman sınırı, Orman sınırı altı 


\section{Introduction}

Stand structure is the physical and temporal distribution of trees and other plants which can be described by species, ages, vertical or horizontal spatial patterns, sizes of living and dead trees or their crown volume, leaf area, stem, stem cross section (Oliver and Larson, 1996). Stand development refers to that part of stand dynamics concerned with changes in stand structure over time (Oliver and Larson, 1996). Both non-human and human-caused disturbances break the stand structure and change resource availability or the physical environment (Pickett and White, 1985; Oliver and Larson, 1996). Natural disturbance regimes have been replaced by disturbances of human origin linked to economic and social development (Piussi, 2000). Land-use and forest-use history is therefore a fundamental determinant in shaping vegetative composition and stand structure in forests. This cultural legacy has important implications for structure and composition of forest ecosystems and also for forest management (Motta and Garbarino, 2003).

Determination of the protector forest trees is very important in forest succession stages. Definition of individual trees is particularly important in old-growth forests. This facilitates the separation of forest succession and can also be used in multi-cohort, mixed species and multi storied stands. The most important criteria in defining individual trees are tree species, diameter at breast height (DBH), height, age and increment (Çolak and Pitterle, 1999).

It is essential to obtain information regarding spatial patterns and age structure to understand the dynamics of stand development, and especially the role of small-scale disturbances (Frelich and Graumlich, 1994). Based on characteristics of stands and the disturbance regimes, stand dynamics can be identified as (1) singlecohort, compositional change dynamics, (2) single-cohort, mono-dominant dynamics, (3) cohort dynamics and (4) fine-scale gap dynamics in boreal forests (Shorohova et al., 2009). Criteria and indicators of hemeroby need to integrate by combining species (e.g. red-listed-, indicator- and umbrella species) with the cohort structures, stages of stand development which are the indicators of stand development patterns (Oliver and Larson, 1996; Brümelis et al., 2011).

It is important to define the concept of natural forests to develop conservation and restoration programmes and set measurable goals (Brümelis et al., 2011). Forests in the Firtına Basin are old-growth forests and have been declared one of the most important forest lands among 100 forest areas in Europe by World Conservation Monitoring Centre (Kurdoğlu and Çokçalıskan, 2011). Determination of cohort structures in oldgrowth forest will make it possible to understand the key factors for the application to management in Turkish forestry. It is therefore essential to know the main features of the stands and the main rules for constructing the best stand structures in managing high mountain forests. Main goals of the study were (1) to determine the cohort structures of the pure and mixed stands of high mountain forests and (2) to take decisions about suitable silvicultural treatments especially for overaged high mountain forests in northeast Turkey.

\section{Materials and method Study area}

In the study, pure and mixed stands of high mountain forests in the Kavron Valley were selected as material. Research area is one of the most valuable forest areas in the northeast of Turkey because of comprising virgin forests and it was located in Çamlıhemşin, south-east Rize $\left(40^{0} 52^{\prime} \mathrm{N}\right.$ $41^{0} 07^{\prime} \mathrm{E}$ ). Subjective sampling was used to maximize spatial variation in the dataset. Sampling was done obviously at three different elevations/vegetation zones (tree line, timberline and sub timberline) as six repetitions regarding two different site aspects. Eighteen 0.04 ha sample plot were sampled in the research area. General characteristics of the sampling plots were given in Table 1. Approximately $2138.1 \mathrm{~mm}$ precipitation fall evenly through the year and annual mean temperature was $5.3{ }^{\circ} \mathrm{C}$ in the research 
Table 1. General information about sampling plots

\begin{tabular}{ccccc}
\hline Sample Plot & Aspect & Altitude $(\mathrm{m})$ & Slope Gradient (\%) & Coordinate (UTM) \\
\hline 1.1 & $\mathrm{~N}$ & 2190 & 24.4 & $679380-4530857$ \\
1.2 & $\mathrm{NE}$ & 2065 & 76.4 & $679560-4530810$ \\
1.3 & $\mathrm{NE}$ & 2020 & 48.0 & $679667-4530811$ \\
2.1 & $\mathrm{E}$ & 2250 & 79.8 & $679282-4531007$ \\
2.2 & $\mathrm{E}$ & 2030 & 65.9 & $679649-4531186$ \\
2.3 & $\mathrm{E}$ & 1980 & 63.6 & $679701-4531150$ \\
3.1 & $\mathrm{NE}$ & 2240 & 72.4 & $679500-4531854$ \\
3.2 & $\mathrm{NE}$ & 2100 & 75.3 & $679916-4531702$ \\
3.3 & $\mathrm{E}$ & 1940 & 60.5 & $679993-4531644$ \\
4.1 & $\mathrm{NW}$ & 2025 & 43.0 & $680658-4531382$ \\
4.2 & $\mathrm{NW}$ & 1930 & 50.7 & $680524-4531520$ \\
4.3 & $\mathrm{NW}$ & 1870 & 30.8 & $680409-4531601$ \\
5.1 & $\mathrm{~W}$ & 2120 & 55.5 & $681081-4531477$ \\
5.2 & $\mathrm{~W}$ & 2020 & 55.9 & $680865-4531647$ \\
5.3 & $\mathrm{~W}$ & 1950 & 64.5 & $680673-4531892$ \\
6.1 & $\mathrm{~W}$ & 2150 & 54.5 & $681040-4531640$ \\
6.2 & $\mathrm{~W}$ & 2100 & 63.9 & $680966-4531738$ \\
6.3 & $\mathrm{NW}$ & 1975 & 62.8 &
\end{tabular}

\section{Data collection}

Altitudes, aspects, slope gradients and UTM coordinates were measured with GPS. Slope gradients were measured with inclinometer. All standing trees were marked and diameters at breast height (DBH) were measured with compass. Heights were also measured with digital height meter. Ages were measured with increment cores at DBH. Increment cores were taken from the trees in different diameter and height classes. Diameter classes were arranged at $4-\mathrm{cm}$ intervals, height classes at 5-meter intervals and age classes at 10-year intervals. 5 meter which is the threshold height for being regarded as a tree (Rushforth, 1999) was assumed to be practicable in determining storied structure.

Ordinate position and crown projection maps were drawn. Spatial distributions of trees, tree collective characteristics and crown density were defined by stand profiles (Aksoy, 1978; Odabaşı, 1976; Liu, 1997; Demirci et al., 2002; Üçler et al., 2001; Yücesan, 2006; Üçler et al., 2007).

Mixed stands are distinguished whenever each tree species in the mixture occupies at least $10 \%$ of stand volume or basal area in Turkish forest management (Anonymous, 2012). Tree species ratios were determined with the criteria of basal area and the number of the tree species in mixed stands.

Times to reach breast height for each tree species were identified in order to compare the height growth rate abilities of different tree species in the stand structure. Time to reach breast height was calculated during the field study. After determining more than three individuals at breast height for every tree species, their ages were calculated, and the average of the calculated ages for each tree species was taken as year to reach breast height (Üçler et al., 2001; Üçler et al., 2007; Yücesan, 2006; Yücesan et al., 2010).

\section{Statistical analysis}

SPSS was used for statistical analysis. Conformity of the frequency distributions of $\mathrm{DBH}$, height and age variables with normal distribution was tested (Harter et al., 1984, Kalıpsız, 1988, Siegel and Castellon, 1995) by One-Sample Kolmogorov-Smirnov Test $(\alpha \leq 0.05)$.

Coefficients of variation (CV\%) were calculated to compare diameter, height and age distributions and tree species composition. In comparison, if the coefficients of variations were greater than $50 \%$, structure were defined as multi-cohort stand because of the heterogeneity (Üçler et al., 2001; Demirci et al., 2002; Yücesan, 2006; Yücesan et al., 2010).

\section{Determination of cohort structures}

Frequency curves of $\mathrm{DBH}$, height and age were used to determine cohort structures. Single-cohort structures tend to have normal or skewed-normal DBH distributions. Multicohort structures represent intermixtures of species and ages with no obvious boundaries separating them. Two or more age or species groups can be distinguished within the stand (Brack, 1999). Frequency distribution for 
height is reverse-J shaped (Philip, 1994; Brack, 1999; Firat, 1973; Kalıpsiz, 1984; Davis and Johnson, 1987; Deal et al., 1991; Yücesan et al., 2010). However, frequency distribution of age is generally not suitable for any statistical distribution (Loetsch et al., 1973). Trees in different age classes may be observed in multi-cohort stands, but due to differing degrees of pressure, there are many kinds of difference between DBH and height values of trees in the same age classes (Vanclay, 1994). Consequently, frequency distribution of $\mathrm{DBH}$ is more explanatory than frequency distribution of age in multi-cohort stands (Yücesan, 2006; Yücesan et al., 2010).

\section{Results}

Stands can range from single-cohort to multi-cohort stands in the research area. Most of the treeline stands were in multicohort structure according to the diameter distributions. Height distributions were also as in multi-cohort structure in some of treeline stands. Age variations in treeline stands ranged from 10 to 150 years. Two stands in treeline showed two-storied structure, three stands showed multi-storied structure and one stand showed selection structure. Age variations in timberline stands ranged from 15 to 270 years. However, age variations ranged from 13 to 105 years in the sub-timberline stands. There was no single or two-storied structure in the timberline and sub-timberline stands. Only one stand in timberline showed selection structure. Other stands showed multi-storied structure that storey numbers ranged from 3 to 6 . Diameters were generally within normal distribution in timberline and sub-timberline stands, but diameter distribution was as in multi-cohort structure only in one timberline stand. Comparable results were observed in height distributions. Usually height distribution was in normal distribution in the timberline. However, negative exponential distribution was observed in the timberline as well.

As shown in Table 2, frequency distributions of $\mathrm{DBH}$, height and age were within normal distribution in 5 of the treeline stands $(p<0.05)$. Our results also showed that $\mathrm{DBH}$, height and age variables were within normal distribution $(p<0.05)$ in the timberline and sub-timberline stands. Although all sampling plots must be assessed as in singlecohort structure according to statistical analysis, but there is a conflict with some other results described above and below as well.

Homogeneity was demolished towards treeline from sub-timberline according to the diameter, height and age variables. In other words, coefficients of variances were increased (Table 3). Age intervals were higher in the treeline and timberline stands than the sub-timberline stands. Coefficients of variation more than $50 \%$ were obtained in 4 of the treeline stands according to the age factor. It was also more than $50 \%$ in 3 of the timberline stands and in 1 of the subtimberline stand. On the other hand, softwood species were more heterogenic than broadleaved species. Spruce was more heterogenic than fir. The greatest heterogeneity in broadleaved tree species was observed in beech. Mixed species structures were also more heterogenic in terms of age, diameter and height variables (Table 3).

Spatial distributions of tree species were not random in treeline stands. Tree collectives and large gaps between tree collectives were widely common in treeline stand structures. Numbers of trees ranged from 2 to 17 individuals in the treeline tree collectives. Numbers of tree collectives ranged from 6 to 7 in the treeline. Mean area per tree in tree collectives was $1.77 \mathrm{~m}^{2}$ in the treeline. Spatial distributions of the trees were random, and exact differences were also observed in tree collective characteristics in the timberline and subtimberline stands. Numbers of trees in collectives ranged from 3 to 9 in the timberline and 2 to 3 in the sub-timberline stands. Numbers of tree collectives ranged from 2 to 5 in the timberline and 2 to 3 in the sub-timberline stands. Mean area per tree in tree collectives was $2.56 \mathrm{~m}^{2}$ in the timberline and $2.51 \mathrm{~m}^{2}$ in the sub-timberline stands.

Spruce and fir exhibited similar growth rate ability in the timberline and subtimberline stands because of the positive canopy effect. However, in the treeline stands there was a considerable difference in favour of fir. Height growth rate was 
significantly in favour of beech in the timberline and sub-timberline stands. Beech had double height growth rate than other tree species in the sub-timberline stands. Height growth rate of beech and fir was nearly similar in treeline and timberline. Spruce was the most dominant tree species in the subalpine forests in the research area but, height growth rates of mountain ash and spruce were similar in treeline stands. There were no mountain ash and trembling poplar in the timberline and sub-timberline stands (Table 4).

Table 2. Results of One Sample Kolmogorov-Smirnov test

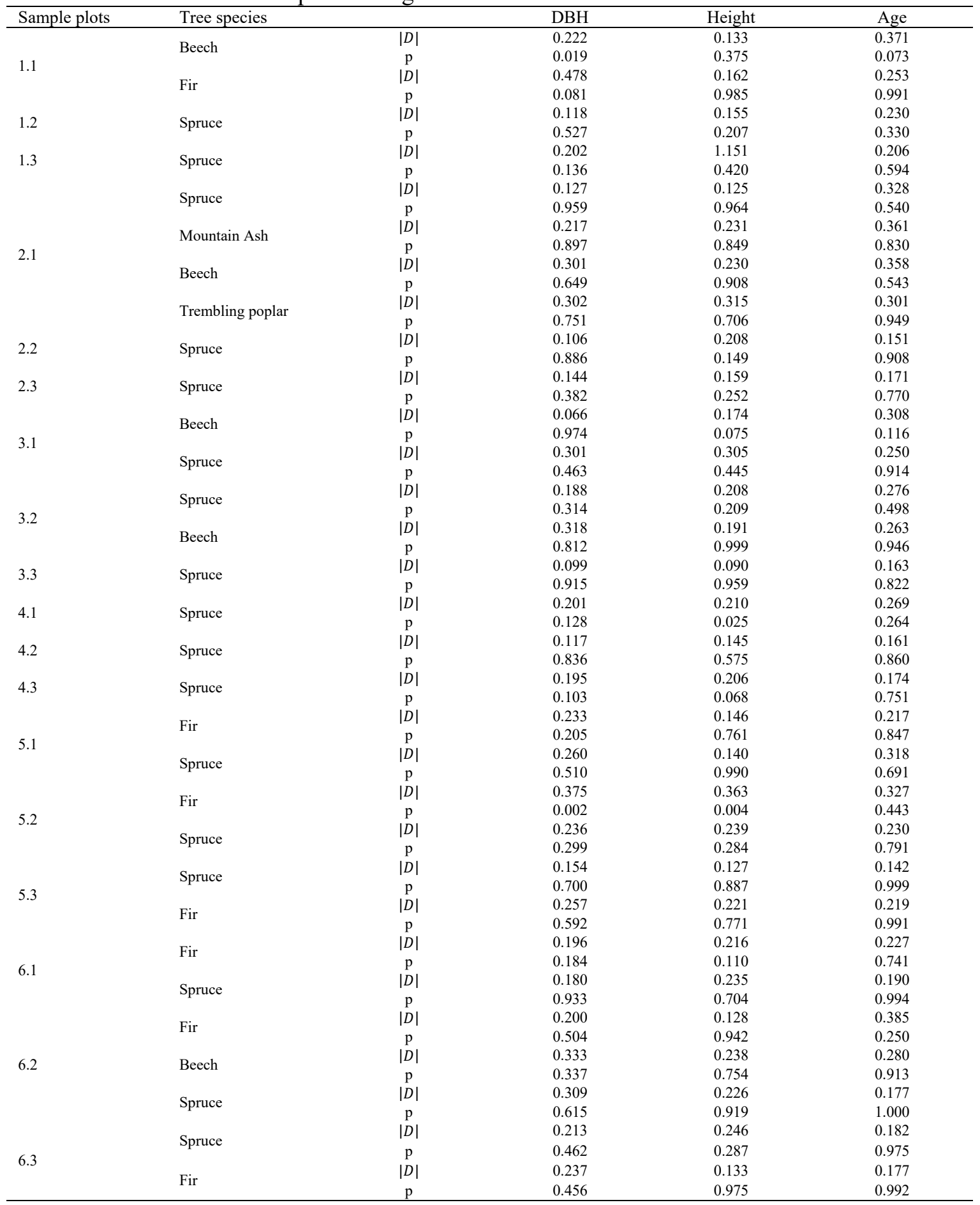


Table 3. Variation coefficients according to dbh, height and age variables.

\begin{tabular}{clccc}
\hline \multirow{2}{*}{ Sample plots } & Tree species & \multicolumn{3}{c}{ Coefficients of } \\
& & Variation (CV\%) & Height & Age \\
\cline { 2 - 5 } & Beech & 72 & 36 & 29 \\
& Fir & 20 & 22 & 9 \\
1.1 & Spruce & 58 & 55 & 22 \\
1.2 & Spruce & 71 & 63 & 36 \\
& Spruce & 53 & 38 & 26 \\
& Mountain Ash & 21 & 19 & 30 \\
2.1 & Beech & 20 & 27 & 28 \\
& Trembling poplar & 64 & 36 & 29 \\
& Spruce & 56 & 71 & 25 \\
2.2 & Spruce & 71 & 49 & 44 \\
2.3 & Beech & 41 & 28 & 29 \\
3.1 & Spruce & 98 & 97 & 56 \\
& Spruce & 65 & 57 & 68 \\
3.2 & Beech & 53 & 32 & 71 \\
3.3 & Spruce & 43 & 36 & 18 \\
4.1 & Spruce & 97 & 85 & 65 \\
4.2 & Spruce & 61 & 53 & 28 \\
4.3 & Spruce & 85 & 75 & 57 \\
5.1 & Fir & 28 & 24 & 20 \\
& Spruce & 72 & 56 & 61 \\
5.2 & Fir & 100 & 100 & 73 \\
& Spruce & 100 & 76 & 48 \\
& Spruce & 66 & 53 & 27 \\
5.3 & Fir & 41 & 35 & 26 \\
& Fir & 74 & 79 & 57 \\
6.1 & Spruce & 95 & 100 & 57 \\
& Fir & 58 & 53 & 61 \\
& Beech & 55 & 29 & 29 \\
6.2 & Spruce & 67 & 45 & 20 \\
& Spruce & 64 & 56 & 29 \\
& Fir & 63 & 39 & 7 \\
\hline & & & &
\end{tabular}

Table 4. Average years to reach breast height

\begin{tabular}{|c|c|c|c|c|c|c|c|c|c|c|c|c|c|c|c|}
\hline \multirow{2}{*}{$\begin{array}{l}\text { Sampling } \\
\text { Unit }\end{array}$} & \multicolumn{5}{|c|}{ Treeline } & \multicolumn{5}{|c|}{ Timberline } & \multicolumn{5}{|c|}{ Sub-timberline } \\
\hline & $\mathrm{S}$ & $\mathrm{B}$ & $\mathrm{F}$ & $\mathrm{P}$ & A & $\mathrm{S}$ & $\mathrm{B}$ & $\mathrm{F}$ & $\mathrm{P}$ & A & $\mathrm{S}$ & $\mathrm{B}$ & $\mathrm{F}$ & $\mathrm{P}$ & A \\
\hline 1 & - & 25 & 28 & - & - & 28 & - & - & - & - & 20 & - & - & - & - \\
\hline 2 & 43 & 34 & - & 21 & 43 & 29 & - & - & - & - & 23 & - & - & - & - \\
\hline 3 & 45 & 25 & - & - & - & 29 & 19 & - & - & - & 26 & - & - & - & - \\
\hline 4 & 49 & - & - & - & - & 38 & - & - & - & - & 24 & - & - & - & - \\
\hline 5 & 48 & - & 32 & - & - & 39 & - & 29 & - & - & 24 & - & 23 & - & - \\
\hline 6 & 39 & - & 35 & - & - & 33 & 27 & 30 & - & - & 22 & - & 19 & - & - \\
\hline Average & 45 & 28 & 32 & 21 & 43 & 33 & 23 & 30 & - & - & 23 & 14 & 21 & - & - \\
\hline
\end{tabular}

Eight of the sampled stands were pure stands and 10 sampled stands were mixed stands. Mixed stands in the treeline were composed of mountain ash, trembling poplar, beech, spruce and fir. The numbers of tree species in species mixture differed in timberline and sub-timberline stands. In the treeline, 5 sampled stands were mixed stands, compared to 3 in the timberline and 2 in the sub-timberline. Mixtures of spruce, beech and fir were observed in the timberline stands, but tree species in mixtures were spruce and fir in the sub-timberline stands (Table 
Table 5. Mixture ratio of the tree species

\begin{tabular}{|c|c|c|c|c|c|c|c|c|c|c|c|c|c|c|c|}
\hline \multirow{2}{*}{ Sampling Unit } & \multicolumn{5}{|c|}{ Treeline $(\%)$} & \multicolumn{5}{|c|}{ Timberline (\%) } & \multicolumn{5}{|c|}{ Sub-timberline $(\%)$} \\
\hline & $\mathrm{S}$ & $\mathrm{B}$ & $\mathrm{F}$ & $\mathrm{P}$ & A & $\mathrm{S}$ & $\mathrm{B}$ & $\mathrm{F}$ & $\mathrm{P}$ & A & $\mathrm{S}$ & $\mathrm{B}$ & $\mathrm{F}$ & $\mathrm{P}$ & $\mathrm{A}$ \\
\hline 1 & - & 85 & 15 & - & - & 100 & - & - & - & - & 100 & - & - & - & - \\
\hline 2 & 47 & 18 & - & 15 & 20 & 100 & - & - & - & - & 100 & - & - & - & - \\
\hline 3 & 87 & 13 & - & - & - & 86 & 14 & - & - & - & 100 & - & - & - & - \\
\hline 4 & 100 & - & - & - & - & 100 & - & - & - & - & 100 & - & - & - & - \\
\hline 5 & 32 & - & 68 & - & - & 41 & - & 59 & - & - & 70 & - & 30 & - & - \\
\hline 6 & 22 & - & 78 & - & - & 19 & 26 & 55 & - & - & 55 & - & 45 & - & - \\
\hline
\end{tabular}

\section{Discussion}

Opinions differ regarding the nature of single-cohort or multi-cohort stand structures. The main question is how the age cohort interval should be assessed. Kapucu (1992) suggested that distribution of age cohorts of more than 5 years intervals might be sufficient for recognition of multi-cohort structure. From that perspective, all the sampled stands should be regarded as multicohort stands. However, Philip (1994) proposed that in a single-cohort structure the age interval between trees should be at least $25 \%$ of the rotation period. The rotation period is regarded as roughly 100 years in natural, widely spread, slow-height growth rate tree species stands in productive forest lands in Turkey.

Natural regeneration can be very prolonged because of lack of habitat, short vegetation period, poor levels of seed propagation and etc. in the subalpine zone. In addition, the genetic characteristics of different tree species also affect the rotation period. The varying growth abilities of different tree species complicate the assessment of the rotation period in mixed stands. Low height growth rate in early years is one of the most conspicuous characteristics of the subalpine zone (Indermühle, 1978). It may take 50 years or more to reach at breast height in the subalpine zone in Picea abies stands (Indermuhle, 1978). After DBH has been attained, levels of height growth may be similar to those in lower altitude stands. Pinus cembra in the Italian Alpine region is able to reach $120 \mathrm{~cm}$ height meanly in 44 years (Motta and Dotta, 1994). Averaged time to reach at breast height in Picea orientalis stands in timberline is 22 years, and 42 years in treeline stands (Üçler et al., 2001; Üçler et al., 2007). Therefore, identification of rotation period must be reassessed according to subalpine factors and should be longer than in productive forests.

The results of this research support those of previous studies. The time required for trees to reach at breast height decreases towards timberline and sub-timberline. Picea orientalis and Sorbus aucuparia exhibit similar growth ability in the treeline. Fagus orientalis, Abies nordmanniana and Acer platonoides may be regarded as similar according to their height growth rate in the treeline. Populus tremula exhibits the maximum height growth rate than the other tree species in the treeline; however, Populus tremula can only be seen in treeline.

Height growth rates of the tree species were closer to each other in timberline and sub-timberline stands; however, the height growth rate differed in treeline. It is clear that treeline needs to be evaluated as a more critical habitat than timberline and subtimberline. Diameter distributions were generally close to normal distribution in the timberline and sub-timberline. Also, there were some negative exponential or reverse Jshaped distributions in the timberline and sub-timberline. However, although diameter, age and height distributions were not commonly in negative exponential or reverse $\mathrm{J}$-shaped distribution in the timberline and sub-timberline stands, age intervals were more than 40 years; height distributions referred to multi-storied structure and different development stages such as thicket, pole and pole size timber can be seen. On the other hand, variation coefficients of diameter, age and height variables increase from sub-timberline towards treeline stands. Both tree numbers in the tree collectives and the number of tree collectives in treeline stands were more than timberline and subtimberline stands (Üçler et al., 2007; Mayer and Ott, 1991; Mayer and Pitterle, 1988; 
Yücesan, 2006; Yücesan, 2010). While tree ages in a tree collective are nearly the same, age interval ranges widely between different tree collectives (Ott, 1995; Yücesan, 2006; Yücesan, 2010). This seems to be one of the important reasons for heterogeneity and the multi-cohort structure in treeline stands.

Consequently, large age interval, multistoried stand structure and coefficients of variations more than $50 \%$ should be refer to multi-cohort stand in high mountain forests. The main types of tree age structures based on tree distributions in 40-year-wide age cohorts were distinguished by Dyrenkov (1984), who emphasised that tree age and diameter distributions, spatial structure and successional pathways affect stand structure. Normal distribution is not sufficient for referring to single-cohort structure in high mountain forests. Different growth rates of the trees and tree species cause storied structure (Lorimer, 1981). If the overstorey species are able to survive in the reduced light beneath the dominating species, they can form an understorey. In addition, root competition and species specific height growth rate ability are also important. Such stands are commonly referred to as multistoried, mixed species stands. The height growth rate of understorey tree species slows down because of the reduced light and root competition. However, they still continue living. Eventually, the continued height growth of the over storey trees and the lower height growth rate of the trees in understorey, make the dominating trees much larger. Such multi-storied, single-cohort, mixed stands have been mistaken for multi-cohort stands (Wierman and Oliver, 1979; Oliver, 1980; Johnson, 1980; Larson, 1986; Smith, 1986).

Our results show that in subalpine forests multi-cohort structure is widely seen. The selective system is the most suitable silvicultural system for multi-cohort structure. The selection method allocates the space previously occupied by nature trees to the new age class. It must provide at least the minimum amounts of light, nutrients and moisture to insure survival and development of the new age class following seed germination (Nayland, 1996). The idea of reintroducing the selective system and other multi-cohort silvicultural systems back to forestry has recently been suggested and widely discussed in Scandinavian countries and Russia as important tools for sustainable forestry (Angelstam, 1998; Kuuluvainen, 2002; Lähde et al., 1999; Volkov, 2003). Modification of uneven-aged management regimes to include occasional harvests of variable intensity and spatial pattern may help avoid the decline in species diversity that tends to occur after many decades of conventional uneven-aged management. At the same time, a multi-cohort system with these properties would retain a high degree of average crown cover, promote structural heterogeneity typical of old-growth forests, and maintain dominance by late-successional species (Hanson and Lorimer, 2007).

Subalpine stands have a variety of forest functions. However, while they show similar structures, their prior functions can be changed. Stand structures are the main factors in sustaining forest functions. Otherwise, if stand structures change, degradation of forest ecosystems may occur. Anthropogenic impacts are often seen in high mountain forests. Restoration or rehabilitation is very important in these anthropogenic forests. Mixed species stands have a greater ability to form a multi-storied stand structure than pure stands. Multistoried stands are more stable than singlestoried stands. Additionally, softwood tree species are more stable than hardwood tree species. Softwood tree species are therefore more common in subalpine forests. In the study area, mixed stands of Sorbus aucuparia, Populus tremula, Fagus orientalis, Picea orientalis and Abies nordmanniana were observed. However, in timberline and sub-timberline stands Picea orientalis, Fagus orientalis and Abies nordmanniana were the species in the mixture and Picea orientalis is the main tree species in treeline, timberline and subtimberline stands. Harsh ecological conditions and lack of habitat cause the transformation from mixed species stands to pure stands.

\section{Conclusion}

Multi-cohort structures and collective structuring ability are the key factors in silvicultural treatments in high mountain 
forests. Silvicultural treatment such as singletree selection method, patch and group selection method can be provided because of being suitable for multi-cohort structure. Each small sub-unit could be regenerated from seed produced by the seed sources of adjacent groups if seed bed conditions and other factors were suitable for natural regeneration.

Additionally, in restoration or rehabilitation treatments for anthropogenic forests, afforestation applications should be organised according to the rules of construction of multi-cohort structures by tree collectives. Each tree collective should be in single-cohort structure. However, multi-cohort structure should be created by clusters include collectives in different age classes and by the way stability can be maintained more effectively. Both softwood and hardwood tree species appropriate to subalpine habitat conditions should be combined in afforestation applications in high mountain forests.

\section{Acknowledgement}

This study was carried out for a Doctoral dissertation at Karadeniz Technical University Institute of Science and Technology. The Doctoral dissertation was supported by Karadeniz Technical University Research Fund, Project number 2003.113.001.2.

\section{References}

Aksoy, H. (1978). Silvicultural features of Karabük Büyükdüz Research Forest. Istanbul: Istanbul University Press No: 2332/237.

Angelstam, P.K. (1998). Maintaining and restoring biodiversity in European boreal forests by developing natural disturbance regimes. J. Veg. Sci., 9: 593-602.

Anonymous (2012). The principles and procedures for implementation of the ecological based functional forest management plans. Available $<$ http://web.ogm.gov.tr/birimler/ merkez/Amenajman/Dokumanlar/295\%20 SAYILI\%20TEBL\%C4\%B0\%C4\%9E.pd $\mathrm{f}>$ [accessed 13.01.2014]

Brack, C. (1999). Forest measurement and modelling. Available $<$ http://sres- associated.anu.edu.au/mensuration/s stru ct.htm> [accessed 13.01.2014]

Brūmelis, G., Jonsson, B.G., Kouki, J. Kuuluvainen, T., Shorohova, E. (2011). Forest naturalness in northern Europe: perspectives on processes, structures and species diversity. Silva Fennica, 45(5): 807-821.

Davis, L.S., Johnson, K.N. (1987). Forest Management (Third edition). New York: McGraw-Hill Book Company Inc.

Deal, R.L., Oliver, C.D., Borman, B.T. (1991). Reconstruction of mixed species hemlock spruce stands in coastal South Alaska. Can. J. For. Res., 21(5): 643-654.

Demirci, A., Yavuz, H., Üçler, A.Ö., Oktan, E., Yücesan, Z. (2002). Stand structures, growth and increment relations and silvicultural suggestions in pure oriental spruce forests. Trabzon: The Scientific and Technological Research Council of Turkey, Project No: TARP-2051.

Dyrenkov, S.A. (1984). Structure and dynamics of boreal spruce forests. Leningrad: Nauka publications.

Firat, F. (1973). Dendrometry. Istanbul: Istanbul University Press No:1890/193.

Frelich, L.E., Graumlich, L.J. (1994). Ageclass distribution and spatial patterns in an old-growth hemlock-hardwood forest. Can. J. For. Res., 24: 1939-1947.

Hanson, J.J., Lorimer, C.G. (2007). Forest structure and light regimes following moderate wind storms: implications for multi-cohort management. Ecological Applications, 17(5): 1325-1340.

Harter, H.L., Khamis, H.J., Lamb, R.E. (1984). Modified Kolmogorov-Smirnov Tests for goodness of fit. Comm. Stat. Smul. Comput., 13: 293-323.

Indermühle, M.P. (1978). Struktur-, Altersund Zuwachsuntersuchungen in einem Fichtenplenterwald der subalpinen Stufe. Zürich: Diss. ETH Nr.5926.

Johnson, E.A. (1980). Fire recurrence and vegetation in the lichen woodlands of the Northwest Territories, Canada. In: Proceedings of the Fire History Workshop. USDA Forest Service General Technical Report RM-GTR-81, Tucson, Arizona, pp. 110-114.

Kalıpsız, A. (1984). Dendrometry. Istanbul: Istanbul University Press No: 3194/354. 
Kalıpsı, A. (1988). Statistical Methods. İstanbul: Istanbul University Press No: 3522/394.

Kapucu, F. (1992). Natural mixed stand structures in East Blacksea Region and application of some stand parameters in realizing mixed stand structures. Journal of İstanbul University Faculty of Forestry, 38 (B1): 107-112.

Kurdoğlu, O., Çokçalışkan, B.A. (2011). Assessing the effectiveness of protected area management in the Turkish Caucasus. African Journal of Biotechnology, 10 (75): 17208-17222.

Kuuluvainen, T. (2002). Natural variability of forests as a reference for restoring and managing biological diversity in boreal Fennoscandia. Silva Fenn., 36: 97-125.

Lähde, E., Laiho, O., Norokorpi, Y. (1999). Diversity-oriented silviculture in the boreal zone of Europe. For. Ecol. Manage., 118: 223-243.

Larson, B.C. (1986). Development and growth of single-cohort stands of Douglas-fir and grand fir. Canadian Journal of Forest Research, 16:367-372.

Liu, Q.J. (1997). Structure and dynamics of the subalpine coniferous forest on Changbai mountain, China. Plant Ecology, 132: 97-105.

Loetsch, F., Haller, K.E., Zohrer, F. (1973). Forest Inventory (2nd edition). Munchen: BLV Verlagsgesellschaft.

Lorimer, C.G. (1981). Survival and growth of understory trees in oak forests of the Hudson Highlands, New York. Can. J. For. Res., 11: 689-695.

Mayer, H., Ott, E. (1991). Gebirgswaldbau Schutzwaldpflege. Stuttgart \& New York: Gustav Fischer Verlag.

Mayer, H., Pitterle, A. (1988). Osttiroller Gebirgswaldbau: Waldbauliche Schluss folgerungen aus den Hochwasserkatostrophen 1965 und 1966. Wien: Institut für Waldbau, Universität für Bodenkultur.

Motta, R., Dotta, A. (1994). Some aspects of Cembran pine regeneration in the Italian Cottion Alps. In: Proceedingsinternational workshop on subalpine Stone pines and their environment: the status of our knowledge. USDA, Forest Service, Intermountain Research Station,
General Technical Report INT-GTR, St. Moritz, Switzerland.

Motta, R., Garbarino, F. (2003). Stand history and its consequences for the present and future dynamic in two silver fir (Abies alba Mill.) stands in the high Pesio Valley (Piedmont, Italy). Ann. For. Sci., 60: 361-370.

Nayland, R.D. (1996). Silviculture (Concepts and Applications). New York: McGrawHill Companies, Inc.

Odabaşı, T. (1976). Coppice and coppice with standards forests in Turkey and opportunity studying about the conservation of coppice into high forest. Istanbul: Istanbul University Press No: 2079/218.

Oliver, C.D. (1980). Single-cohort development of mixed species stands. Journal of Forestry, 76: 352-354.

Oliver, C.D., Larson, B.C. (1996). Forest Stand Dynamics. New York: Wiley\&Sons.

Ott, E. (1995). Eigenart und Verjüngung der Gebirgsnadelwälder. Zürich: Swiss Federal Institute of Technology.

Philip, M.S. (1994). Measuring trees and forests (2nd edition). Wallingford: $\mathrm{CAB}$ International, Oxon.

Pickett, S.T.A., White, P.S. (1985). The ecology of natural disturbance and patch dynamics. New York: Academic Press.

Piussi, P. (2000). Expansion of European mountain forests. In: Price M.F, Butt N (eds), Forests in Sustainable Mountain Development: A State of Knowledge Report for 2000. Wallingford: CABI Publishing, pp. 19-25.

Rushforth, K. (1999). Trees: Of Britain and Europe (Collins Wild Guide). New York: HarperCollins.

Shorohova, E., Kuuluvainen, T., Kangur, A., Jõgiste, K. (2009). Natural stand structures, disturbance regimes and successional dynamics in the Eurasian boreal forests: a review with special reference to Russian studies. Ann. For. Sci., 66: 201-220

Siegel, S., Castellon, N.J.Jr. (1995). Nonparametric statistics for behavioural sciences (2nd edition). New York: McGraw-Hill Book Company. 
Smith, D.M. (1986). The Practice of Silviculture (8th edition). New York: Wiley\&Sons.

Üçler, A.Ö., Demirci, A., Yavuz, H., Yücesan, Z., Oktan, E., Gül, A.U. (2001). Determination of stand structure and functional examination of pure oriental spruce (Picea orientalis (L.) Link) stands near alpine zone. Trabzon: The Scientific and Technological Research Council of Turkey, Project No: TARP-2215.

Üçler, A.Ö., Yücesan, Z., Demirci, A., Yavuz, H., Oktan, E. (2007). Natural tree collectives of pure Oriental spruce (Picea orientalis (L.) Link.) on mountain forests in Turkey. Journal of Environmental Biology, 28 (2): 295-302.

Vanclay, J.K. (1994). Modelling Forest Growth and Yield: Applications to Mixed species Tropical Forests. Wallingford: $\mathrm{CAB}$ International.

Volkov, A.D. (2003). The bio-ecological basics of exploitation of spruce forests in the north-west of taiga zone of Russia. Petrozavodsk: Karelian Science Centre of Russian Academy of Sciences.

Wierman, C.A., Oliver, C.D. (1979). Crown Stratification by Species in Single-cohort Mixed stands of Douglas fir/Western Hemlock. Can. J.For. Res., 9:1-9.

Yücesan, Z. (2006). Analysis of pure and mixed stand dynamics in high mountain forests in Çamlıhemşin-Fırtına Valley. Doctoral Dissertation, Karadeniz Technical University, Trabzon.

Yücesan, Z., Üçler, A.Ö., Oktan, E. (2010). Structure and development in subalpine pure oriental spruce (Picea orientalis L.Link) stands in Turkey. Austrian Journal of Forest Science, 2: 111-130. 